\title{
Cucumber (Cucumis sativus) Transplants as Affected by Shade Level: Microenvironment, Growth, Photosynthetic Efficiency, Osmoprotectants, Plant Water Status, and Leaf Mineral Nutrients
}

\author{
Semida WM, Mohamed SA* and El-Sawah NA \\ Department of Horticulture, Fayoum University, Egypt
}

Submission: November 20, 2017; Published: December 18, 2017

"Corresponding author: Mohamed SA, Department of Horticulture, Fayoum University, Egypt Tel: +201010787788; Fax: +20 84 6334964; Email:wms00@fayoum.edu.eg

\begin{abstract}
Growing vegetables transplants under black shade nets is currently becoming popular to provide protection from high intensities of light and high temperatures. This study evaluated the effects of shade level on microenvironment, vegetative growth, photosynthetic pigments, chlorophyll a fluorescence, osmoprotectants, plant water status, and leaf mineral nutrients of greenhouse-grown summer cucumber transplants at $25 \%$, $50 \%, 63 \%$, and $75 \%$ shade levels. Overall this study, solar radiation decreased with increased shading levels. Average daily temperatures were approximately decreased by $1.5{ }^{\circ} \mathrm{C}$ under $75 \%$ shade nets compared to the $25 \%$ shade nets. Vegetative growth characteristics, photosynthetic pigments, chlorophyll a fluorescence, leaf mineral nutrient, and dehydration tolerance increased when shade level increased. While, clear decreases in free proline, soluble sugars, and total free amino acids with increased shade level have been observed. This study suggests that, nets with higher shading levels ( 63 and/or $75 \%$ ) are a potential alternative to alleviate photo-inhibition and heat stress in cucumber transplants production.
\end{abstract}

Keywords: Cucumber transplants; Shading nets; Microenvironment; Dehydration tolerance

\section{Introduction}

In traditional vegetable-producing regions, transplanting is a well-known technique used especially for higher valued vegetables to improve growth performance and productivity. However, young vegetable seedlings transplants in arid and/or semiarid regions are often exposed to environmental stresses of various levels depending on the season, such as drought and heat stresses [1]. In greenhouse system there are many effective growth factors such as temperature, relative humidity, light and solar radiation. Of all the climatic factors affecting vegetable production, temperature is considered as one of the most important factors. Global temperature has increased by 0.3-0.6 ${ }^{\circ} \mathrm{C}$ since the late 19 th century and by $0.2-0.3{ }^{\circ} \mathrm{C}$ over the last 40 years.

In the last 140 years, the 1990s was the warmest period [2]. Temperature affects growth and development of vegetables in terms of seed germination, development of economic parts, flowering, pollination, fruit set, quality of produce, seed production, seed storage, seed dormancy and occurrence of disease and pests. Growth and development of most vegetable crops are adversely affected at temperatures less than $5{ }^{\circ} \mathrm{C}$. Growth normally increases with increasing temperatures up to $40{ }^{\circ} \mathrm{C}$, and thereafter it decreases drastically [3]. Moreover, light is the most important environmental parameters that represent the climate of green house, short wave lengths ultraviolet rays, to low energy, long wave length radio waves. Plant life ultimately depends on energy derived from the sun light, and photosynthesis is the only biological important process that can harvest this energy in the form of carbohydrates.

In addition to photosynthesis, there are many other aspects of plant growth most affected by light: chlorophyll synthesis, photoperiod, photomorphogensis, phototropism and photoinhibition [3]. Low-cost protected cultivation, such as plastic tunnels and net houses, has the potential to reduce different biotic and abiotic stresses, which affect productivity and quality [4]. Netting is frequently used to protect transplants and other commercial crops from excessive solar radiation, to 
improve the thermal climate sheltering from wind and hail, and for exclusion of birds and insect-transmitted viral diseases [5-7]. Significant amount of work has been done on the effect of shading material including shade clothes with varying degree of shading , colored shade nets, and partially shade screens [1,4,5,8-11] to reduce the photo-inhibition or/and high temperature caused by light.

Moderate shading could improve the photosynthesis and thereby increase yields and quality through improved carbohydrate supply and efficient water use [12]. Shading effect of black shade nets can lower the inner temperature under the nets with a higher shade factor leading to decreased radiation exposure. The incident of radiation from the sun is partially reflected or absorbed by the shade nets. The part of the radiation that was not reflected or absorbed by the shade nets is transmitted via the nets [13]. However, a negative correlation exists between weight or density of the shade nets and the light transmittance. Lower density of shading gives greater total light transmittance through the nets [14]. Therefore, the objective of the current study was to determine how black shade nets with different degrees of shading $(25 \%, 50 \%, 63 \%$, and $75 \%$ shading with a black net) could influence growth and quality parameters of cucumber transplants.

\section{Materials and Methods}

\section{Lay out and experimentation}

Experiments were conducted at Demo farm, faculty of agriculture, Fayoum, Egypt located at latitude of $29.18{ }^{\circ} \mathrm{N}$ and longitude angle of $30.3^{\circ}$. The experiments aimed to evaluate the response of summer cucumber transplants, hybrid Bahi®, to different degrees of shading nets. Four black shading nets; Shade $75 \%$, Shade $63 \%$, Shade 50\%, and Shade 25\%, according to the manufacturer, were used [15]. Two experiments were conducted during May and August 2014. The experiments were set out as two blocks in which four shading covers were randomly allocated on eight mini tunnels measuring ( $2 \mathrm{~m}$ width X $2 \mathrm{~m}$ height X $3 \mathrm{~m}$ length). Seeds of cucumber were sown in foam trays (84 cells) on May 17th and August 15th 2014, where three trays were allocated within each tunnel. Seed germination media contained peat moss: vermiculite ( $1: 1$ by volume). Transplants were destructively harvested for morphological, physiological, and biochemical measurements $30 \mathrm{~d}$ after sowing [16].

\section{Observation}

Average daily temperatures in each tunnel were measured using Tenmars data loggers (TM305-Temperature/RH Data Logger Neihu, Taiwan). The temperature was measured every $10 \mathrm{~min}$ and then daily average temperature was computed. Total radiation in each tunnel was measured using Data Acquisition system (Tenmars-Solar power meter- TM206, Neihu, Taiwan). Radiation in each tunnel was measured three days a week from (09.00am to $04.00 \mathrm{pm}$ ) every $1 \mathrm{~h}$ and a daily average was computed. 120 destructive transplants after 30 days of sowing were randomly chosen from each treatment (sixty plants per mini tunnel, twenty plants from each tray). Growth measurements included leaf number, leaf area, leaf thickness, stem diameter, shoot length, as well as fresh and dry leaf weights (g) were conducted at destructive harvest.

Dry weight measurements were carried out after drying to constant weight in a ventilated oven at $70{ }^{\circ} \mathrm{C}$. Stem diameter was measured using (Electronic Digital Calipers, Precision Gold, China). Leaf thickness was measured using (Digital Thickness Gauge, Maplin Electronics, UK). Leaf areas were measured using leaf area-leaf weight relationship as illustrated by15 with some modifications as described by 16 . Leaf surface was thoroughly washed in running tap water followed by washing with double distilled water, thereafter 10-20 leaf discs (10-20 $\left.\mathrm{cm}^{2}\right)$ were dried in an oven at $85{ }^{\circ} \mathrm{C}$ for $24 \mathrm{~h}$ to get discs dry weight (DDW). Total leaf area plant- 1 was calculated using the following formula:

$$
\text { Total leaf area plant }{ }^{-1}=\left[\frac{\mathrm{LDW}}{\mathrm{DDW}}\right] \times \mathrm{DA}
$$

Where, LDW is the total leaf dry weight (g), DDW is the discs dry weight and DA is the discs area. Leaf chlorophyll A, B, and carotenoid concentrations (mgg-1 fresh weight) were measured and calculated according to [17]. Membrane stability index (MSI), relative water content (RWC), and electrolyte leakage (EL \%) were determined as described by [18-20] respectively. Leaf N, P, and K contents were determined according to [21-23] respectively. Free proline and Total soluble sugars (TSS) was extracted and measured (in mg per g of leaf DW) in dried leaf tissue as described $[24,25]$ respectively. Total free amino acids were determined as illustrated [26] with some modifications. $0.2 \mathrm{~g}$ dried leaf tissue was extracted in $10 \mathrm{ml}$ of $80 \%(\mathrm{v} / \mathrm{v})$ ethanol and filtered. $5 \mathrm{ml}$ of ninhydrin reagent was added to a $0.1 \mathrm{ml}$ aliquot of the extract, shaken vigorously, and heated in a boiling water bath for $10 \mathrm{~min}$. After cooling, the absorbance was recorded at $570 \mathrm{~nm}$.

Chlorophyll a fluorescence was measured using a portable fluorometer (Handy PEA, Hansatech Instruments Ltd, Kings Lynn, UK). One leaf (the same age) at solar noon was chosen per plant. Maximum quantum yield of PS II Fv/Fm was calculated using the formula; Fv/Fm $=(\mathrm{Fm}-\mathrm{F} 0) / \mathrm{Fm}[27,28]$. Fv/F0 reflects the efficiency of electron donation to the PSII RCs and the rate of photosynthetic quantum conversion at PSII RCs. Fv/F0 was calculated using the formula; Fv/F0 $=(F m-F 0) / F 028$. Performance index (PI) of photosynthesis based on the equal absorption (PIABS) was calculated as reported [29].

\section{Statistical analysis}

All data were subjected to analysis of variance (ANOVA) procedures in Genstat statistical package (version 11) (VSN International Ltd, Oxford, UK). Difference between means was compared using least significant difference test (LSD) at 5\% level. 
Results

\section{Microenvironment}

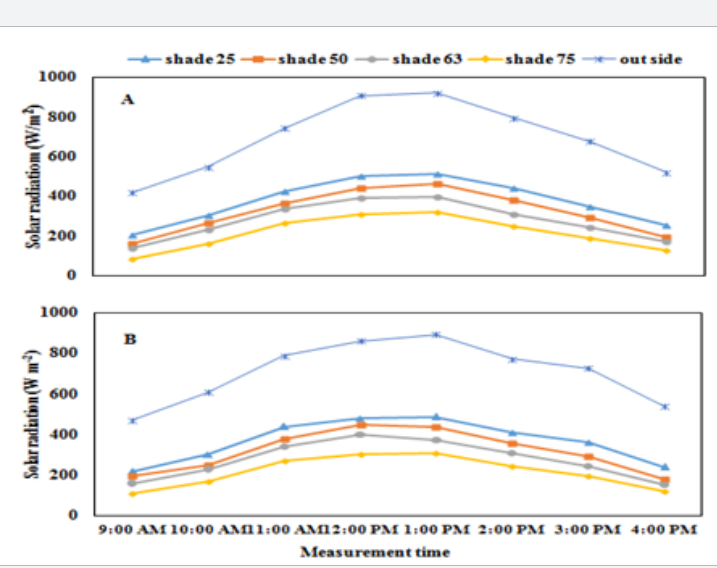

Figure 1: Solar radiation transmission for exp. 1 (A) and exp. 2 (B) under different shade levels in summer cucumber transplants between 9:00 AM and 4:00.

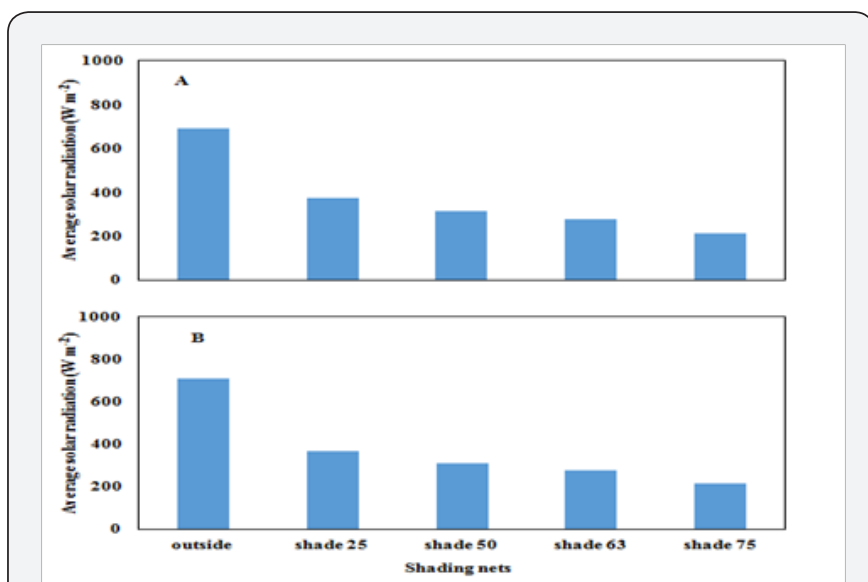

Figure 2: Average solar radiation transmission for exp. 1 (A) and exp. 2 (B) under different shade levels in summer cucumber transplants.

Solar radiation transmission, and mean solar radiation during two growing seasons in 2014 are shown in Figure 1 \& 2 . Mean daily air temperature and average mean temperature are shown in Figure $3 \& 4$. Results showed that solar radiation and temperature have been strongly affected by shading level. Solar radiation and temperature decreased with increased shading levels. Of the tested shading nets, $25 \%$ shade exhibited the highest light transmission compared to other covers with higher shading levels $(50,63$, and $75 \%$ respectively). Temperature has been strongly affected by shading level. The $25 \%$ shade cover appears to give constantly highest average daily temperature, while the $75 \%$ shade nets gave the lowest temperature, and other shading net treatments showed intermediate temperature characteristics. The average daily temperatures under $75 \%$ shade nets were approximately decreased by $1.5^{\circ} \mathrm{C}$, compared to the $25 \%$ shade nets (Figure 3 \& 4 ).
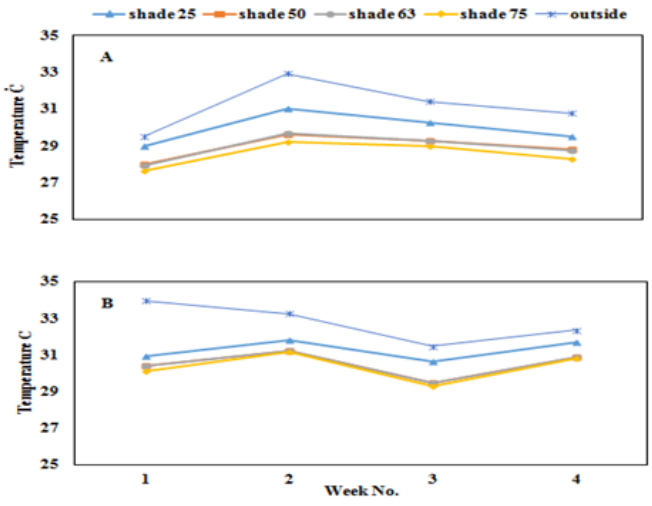

Figure 3: Weekly temperature for exp. 1 (A) and exp. 2 (B) under different shade levels in summer cucumber transplants for the duration of the experiment.

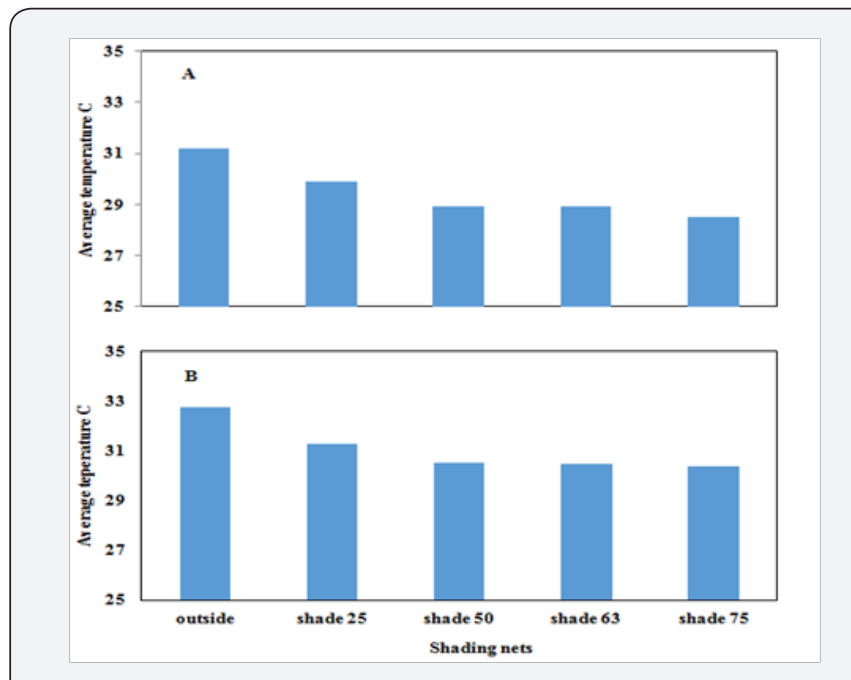

Figure 4: Average temperature for exp. 1 (A) and exp. 2 (B) under different shade levels in summer cucumber transplants.

\section{Vegetative growth and physiological characteris- tics}

Numbers of leaves per transplant, leaf area, shoot length, stem diameter, shoot FW, and Shoot DW increased with increased shade level, whereas leaf thickness was not significantly different among shade levels. Number of leaves per transplant grown under $75 \%, 63 \%$ and $50 \%$ of shading were significantly ( $\mathrm{p}=0.026$ and 0.002 for exp. 1 and 2 respectively) higher as compared to the $25 \%$ shades in both experiments. The average of leaves area was significantly $(\mathrm{p}<0.001)$ higher under $75 \%$ and $63 \%$ shade followed by other shading levels (50 and/or $25 \%$ ) in both experiments (Table 1). Similar trends were observed, in both experiments, for shoot length, stem diameter, shoot FW, and Shoot DW (Table 2). Shoot length and shoot fresh and dry weights were highest $(\mathrm{p}<0.001)$ for shade $75 \%$ followed by shade $63 \%$, shade $50 \%$, and shade $25 \%$. Stem diameter was highest ( $\mathrm{p}=0.02$ and $\mathrm{p}<0.001$ for exp. 1 and 2 respectively) for shade $75 \%$ followed by shade $63 \%$, shade $50 \%$, and shade $25 \%$. 


\section{Agricultural Research \& Technology: Open Access Journal}

Table 1: Effect of shading on number of leaves, leaves area, and leaf thickness of cucumber transplants during the summer season.

\begin{tabular}{|c|c|c|c|}
\hline \multicolumn{1}{|c|}{ Treatment } & Number of Leaves & Leaves Area (Dm2) & Leaf Thickness \\
\hline \multicolumn{4}{|c|}{ Summer Cucumber Exp. (1) } \\
\hline Shade $75 \%$ & $4.85 \pm 0.06 \mathrm{a}$ & $6.87 \pm 0.43 \mathrm{a}$ & $0.52 \pm 0.02 \mathrm{a}$ \\
\hline Shade $63 \%$ & $4.73 \pm 0.07 \mathrm{ab}$ & $5.5 \pm 0.23 \mathrm{~b}$ & $0.48 \pm 0.01 \mathrm{a}$ \\
\hline Shade $50 \%$ & $4.73 \pm 0.07 \mathrm{ab}$ & $3.6 \pm 0.13 \mathrm{c}$ & $0.50 \pm 0.02 \mathrm{a}$ \\
\hline Shade $25 \%$ & $4.55 \pm 0.08 \mathrm{~b}$ & $3.8 \pm 0.16 \mathrm{c}$ & $0.51 \pm 0.04 \mathrm{a}$ \\
\hline \multicolumn{2}{|c|}{ Summer Cucumber Exp. (2) } \\
\hline Shade $75 \%$ & $4.90 \pm 0.05 \mathrm{a}$ & $6.94 \pm 0.43 \mathrm{a}$ & $0.52 \pm 0.03 \mathrm{a}$ \\
\hline Shade $63 \%$ & $4.88 \pm 0.05 \mathrm{a}$ & $5.43 \pm 0.23 \mathrm{~b}$ & $0.48 \pm 0.02 \mathrm{a}$ \\
\hline Shade $50 \%$ & $4.85 \pm 0.06 \mathrm{a}$ & $3.62 \pm 0.13 \mathrm{c}$ & $0.51 \pm 0.02 \mathrm{a}$ \\
\hline Shade $25 \%$ & $4.62 \pm 0.14 \mathrm{~b}$ & $3.98 \pm 0.17 \mathrm{c}$ & $0.41 \pm 0.02 \mathrm{a}$ \\
\hline
\end{tabular}

Table 2: Effect of shading on shoot length, shoot fresh and dry weights, and stem diameter of cucumber transplants during the summer season

\begin{tabular}{|c|c|c|c|c|}
\hline \multicolumn{7}{|c|}{ Treatment } & Shoot Length (Cm) & Shoot Fresh Weight (G) & Shoot Dry Weight (G) & Stem Diameter (Mm) \\
\hline \multicolumn{5}{|c|}{ Summer Cucumber Exp. (1) } \\
\hline Shade 75\% & $4.91 \pm 0.07 \mathrm{a}$ & $2.10 \pm 0.04 \mathrm{a}$ & $0.32 \pm 0.06 \mathrm{a}$ & $4.30 \pm 0.01 \mathrm{a}$ \\
\hline Shade 63\% & $3.79 \pm 0.06 \mathrm{~b}$ & $1.86 \pm 0.04 \mathrm{~b}$ & $0.23 \pm 0.06 \mathrm{c}$ & $4.26 \pm 0.00 \mathrm{a}$ \\
\hline Shade 50\% & $3.55 \pm 0.07 \mathrm{c}$ & $1.77 \pm 0.04 \mathrm{bc}$ & $0.25 \pm 0.07 \mathrm{~b}$ & $4.15 \pm 0.01 \mathrm{a}$ \\
\hline Shade 25\% & $3.55 \pm 0.06 \mathrm{c}$ & $1.69 \pm 0.05 \mathrm{c}$ & $0.20 \pm 0.07 \mathrm{~d}$ & $4.05 \pm 0.00 \mathrm{a}$ \\
\hline \multicolumn{5}{|c|}{ Summer Cucumber Exp. (2) } \\
\hline \multicolumn{7}{|c|}{ Shade 75\% } & $3.58 \pm 0.12 \mathrm{a}$ & $3.20 \pm 0.08 \mathrm{~b}$ & $0.18 \pm 0.01 \mathrm{~b}$ & $3.89 \pm 0.13 \mathrm{a}$ \\
\hline Shade 63\% & $4.31 \pm 0.10 \mathrm{~b}$ & $2.26 \pm 0.09 \mathrm{c}$ & $0.18 \pm 0.01 \mathrm{~b}$ & $3.97 \pm 0.07 \mathrm{a}$ \\
\hline Shade 50\% & $4.42 \pm 0.14 \mathrm{~b}$ & $2.13 \pm 0.06 \mathrm{c}$ & $0.16 \pm 0.00 \mathrm{c}$ & $3.86 \pm 0.11 \mathrm{a}$ \\
\hline Shade 25\% & $3.69 \pm 0.10 \mathrm{c}$ & &
\end{tabular}

Table 3: Effect of shading on chlorophyll a, chlorophyll b, total chlorophyll and carotenoids of cucumber transplants during the summer season

\begin{tabular}{|c|c|c|c|c|}
\hline Treatment & $\begin{array}{c}\text { Chlorophyll a (mg } \\
\text { g-1FW) }\end{array}$ & Chlorophyll b (mg g-1FW) & $\begin{array}{c}\text { Total Chlorophyll (mg } \\
\text { g-1FW) }\end{array}$ & Carotenoids(mg g-1 FW) \\
\hline $\begin{array}{c}\text { Summer Cucumber } \\
\text { Exp. (1) }\end{array}$ & & & & \\
\hline Shade 75\% & $0.66 \pm 0.02 \mathrm{a}$ & $0.57 \pm 0.03 \mathrm{a}$ & $5.40 \pm 0.22 \mathrm{a}$ & $0.14 \pm 0.00 \mathrm{a}$ \\
\hline Shade 63\% & $0.67 \pm 0.04 \mathrm{a}$ & $0.56 \pm 0.04 \mathrm{a}$ & $5.58 \pm 0.45 \mathrm{a}$ & $0.13 \pm 0.02 \mathrm{a}$ \\
\hline Shade 50\% & $0.56 \pm 0.03 \mathrm{~b}$ & $0.44 \pm 0.02 \mathrm{~b}$ & $5.03 \pm 0.30 \mathrm{a}$ & $0.13 \pm 0.01 \mathrm{a}$ \\
\hline Shade 25\% & $0.59 \pm 0.03 \mathrm{ab}$ & $0.50 \pm 0.02 \mathrm{ab}$ & $4.73 \pm 0.24 \mathrm{~b}$ & $0.10 \pm 0.01 \mathrm{~b}$ \\
\hline $\begin{array}{c}\text { Summer Cucumber } \\
\text { Exp. (2) }\end{array}$ & & & \\
\hline Shade 75\% & $0.69 \pm 0.03 \mathrm{a}$ & $0.46 \pm 0.02 \mathrm{a}$ & $4.61 \pm 0.18 \mathrm{a}$ & $0.10 \pm 0.01 \mathrm{a}$ \\
\hline Shade 63\% & $0.61 \pm 0.04 \mathrm{ab}$ & $0.40 \pm 0.02 \mathrm{ab}$ & $4.22 \pm 0.23 \mathrm{a}$ & $0.06 \pm 0.00 \mathrm{~b}$ \\
\hline Shade 50\% & $0.54 \pm 0.02 \mathrm{bc}$ & $0.37 \pm 0.04 \mathrm{~b}$ & $3.55 \pm 0.18 \mathrm{~b}$ & $0.04 \pm 0.01 \mathrm{c}$ \\
\hline Shade 25\% & $0.50 \pm 0.03 \mathrm{c}$ & $0.30 \pm 0.01 \mathrm{c}$ & $3.21 \pm 0.15 \mathrm{~b}$ & $0.04 \pm 0.00 \mathrm{c}$ \\
\hline
\end{tabular}

Table 4: Effect of shading on chlorophyll a fluorescence (Fv/Fm, Fv/F0, and PI) of cucumber transplants during the summer season

\begin{tabular}{|c|c|c|c|}
\hline Treatment & Fv/Fm & Fv/F0 & PI \\
\hline Summer Cucumber Exp. (1) & & & $4.38 \pm 0.06 \mathrm{a}$ \\
\hline Shade $75 \%$ & $0.81 \pm 0.00 \mathrm{a}$ & $3.61 \pm 0.23 \mathrm{~b}$ & $2.43 \pm 0.23 \mathrm{~b}$ \\
\hline Shade $63 \%$ & $0.78 \pm 0.01 \mathrm{ab}$ & $3.33 \pm 0.38 \mathrm{~b}$ & $1.97 \pm 0.22 \mathrm{~b}$ \\
\hline Shade $50 \%$ & $0.73 \pm 0.03 \mathrm{~b}$ & $2.04 \pm 0.28 \mathrm{c}$ & $1.87 \pm 0.51 \mathrm{~b}$ \\
\hline Shade $25 \%$ & $0.66 \pm 0.03 \mathrm{c}$ & & \\
\hline
\end{tabular}




\section{Agricultural Research \& Technology: Open Access Journal}

\begin{tabular}{|c|c|c|c|}
\hline Shade $75 \%$ & $0.79 \pm 0.00 \mathrm{a}$ & $3.74 \pm 0.10 \mathrm{ab}$ & $2.52 \pm 0.17 \mathrm{ab}$ \\
\hline Shade $63 \%$ & $0.79 \pm 0.00 \mathrm{a}$ & $3.76 \pm 0.11 \mathrm{a}$ & $2.54 \pm 0.26 \mathrm{a}$ \\
\hline Shade $50 \%$ & $0.77 \pm 0.01 \mathrm{~b}$ & $3.24 \pm 0.14 \mathrm{~b}$ & $1.26 \pm 0.16 \mathrm{bc}$ \\
\hline Shade $25 \%$ & $0.75 \pm 0.01 \mathrm{c}$ & $2.42 \pm 0.27 \mathrm{c}$ & $0.78 \pm 0.11 \mathrm{c}$ \\
\hline
\end{tabular}

Chlorophyll a, chlorophyll b, total chlorophyll, carotenoids, and chlorophyll a fluorescence (Fv/Fm, Fv/F0, and PI) increased, in both experiments, with increased shade level (Table $3 \& 4$ ). Chlorophyll a, chlorophyll b, total chlorophyll were significantly higher for shade $75 \%$ and/or shade $63 \%$ in both experiments, followed by shade $50 \%$, and shade $25 \%$. Total chlorophyll was highest ( $\mathrm{p}=0.02$ and $\mathrm{p}<0.001$ and for exp. 1 and 2 respectively) for shade $75 \%$ followed by shade $63 \%$, shade $50 \%$, and shade $25 \%$. Similar trends were observed, in both experiments, for carotenoids (Table 3). Carotenoids were highest $(\mathrm{p}<0.01)$, in both experiments, for shade $75 \%$ followed by shade $63 \%$, shade $50 \%$, and shade $25 \%$.

Chlorophyll a fluorescence (Fv/Fm, Fv/F0, and PI) reduced with the increase of solar radiation levels (Table 4). Significant differences were observed in Fv/Fm, and Fv/F0 of plants grown under shade $75 \%$ and/or shade $63 \%$ compared to those plants grown under shade 50\%, and shade $25 \%$. Fv/Fm and Fv/F0 were highest $(\mathrm{p}<0.001)$ in both experiments for shade $75 \%$ followed by shade $63 \%$, shade $50 \%$, and shade $25 \%$. Similarly, plants grown under shade $75 \%$ and/or shade $63 \%$ significantly $(\mathrm{P}<0.001)$ resulted in higher PI than under shade $50 \%$, and shade $25 \%$ (Table 4$)$. Values are means \pm SE $(n=6)$. Mean values in each column followed by a different lower-case-letter are significantly different by Fisher's least-significant difference test (LSD) at $\mathrm{P} \leq 0.05$. Values are means $\pm \mathrm{SE}(\mathrm{n}=10)$. Mean values in each column followed by a different lower-case-letter are significantly different by Fisher's least-significant difference test (LSD) at $\mathrm{P} \leq 0.05$.

Free proline, soluble sugars, and total free amino acids decreased, in both experiments, with increased shade level (Table 5). Significant differences were observed in the concentrations of free proline of plants grown under shade $75 \%$, shade $63 \%$, and shade $50 \%$ compared to those plants grown under shade $25 \%$. Concentrations of free proline were highest $(\mathrm{p}<0.001)$ in both experiments for shade $25 \%$ followed by shade $50 \%$, shade $63 \%$, and shade $75 \%$. Similar trends were observed, in both experiments, for soluble sugars and total free amino acids (Table 5). A soluble sugar was highest for shade $25 \%$ followed by shade $50 \%$, shade $63 \%$, and shade $75 \%$. Total free amino acids was significantly highest ( $\mathrm{p}=0.039$ and $\mathrm{p}=0.005$ for exp. 1 and 2 respectively), in both experiments, for shade $25 \%$ followed by shade $50 \%$, shade $63 \%$, and shade $75 \%$. Values are means \pm SE (n =6). Mean values in each column followed by a different lowercase-letter are significantly different by Fisher's least-significant difference test (LSD) at $\mathrm{P} \leq 0.05$.

Table 5: Effect of shading on free proline, soluble sugars, and total free amino acids of cucumber transplants during the summer season

\begin{tabular}{|c|c|c|c|}
\hline Treatment & $\begin{array}{l}\text { Free Proline } \\
\left(\mathrm{mg} \mathrm{g}^{-1} \mathrm{DW}\right)\end{array}$ & $\begin{array}{l}\text { Soluble Sugars } \\
\left.\text { (mg g }{ }^{-1} \mathrm{DW}\right)\end{array}$ & $\begin{array}{l}\text { Total Free Amino Acids } \\
\text { (mg g-1 DW) }\end{array}$ \\
\hline \multicolumn{4}{|c|}{ Summer Cucumber Exp. (1) } \\
\hline Shade $75 \%$ & $0.26 \pm 0.03 b$ & $0.978 \pm 0.05 b$ & $0.0940 \pm 0.01 \mathrm{~b}$ \\
\hline Shade $63 \%$ & $0.32 \pm 0.02 \mathrm{~b}$ & $1.048 \pm 0.11 b$ & $0.1240 \pm 0.02 b$ \\
\hline Shade $50 \%$ & $0.35 \pm 0.01 b$ & $1.096 \pm 0.08 \mathrm{~b}$ & $0.1360 \pm 0.02 b$ \\
\hline Shade $25 \%$ & $0.60 \pm 0.07 \mathrm{a}$ & $1.316 \pm 0.03 a$ & $0.1840 \pm 0.03 a$ \\
\hline \multicolumn{4}{|c|}{ Summer Cucumber Exp. (2) } \\
\hline Shade $75 \%$ & $0.28 \pm 0.02 \mathrm{c}$ & $1.48 \pm 0.15 \mathrm{a}$ & $0.15 \pm 0.02 \mathrm{~b}$ \\
\hline Shade $63 \%$ & $0.31 \pm 0.03 c$ & $1.54 \pm 0.26 \mathrm{a}$ & $0.14 \pm 0.01 \mathrm{~b}$ \\
\hline Shade $50 \%$ & $0.40 \pm 0.02 b$ & $1.62 \pm 0.12 \mathrm{a}$ & $0.16 \pm 0.01 \mathrm{~b}$ \\
\hline Shade $25 \%$ & $0.57 \pm 0.02 \mathrm{a}$ & $1.68 \pm 0.16 \mathrm{a}$ & $0.21 \pm 0.01 \mathrm{a}$ \\
\hline
\end{tabular}

\section{Plant water status and leaf mineral nutrients}

Data shown in Table 6 reveal that relative water content (RWC), membrane stability index (MSI), and electrolyte leakage (EL) of cucumber transplants were significantly affected, in both experiments, by shade level. Cucumber transplants grown under shade $75 \%$ and/or shade $63 \%$ revealed a significant increase in dehydration tolerance in terms of increased RWC and MSI and reduced EL compared to those plants grown under shade $50 \%$, and shade $25 \% . \%$. RWC was significantly highest ( $\mathrm{p}=0.02$ and p $<0.001$ for exp. 1 and 2 respectively), in both experiments, for shade $75 \%$ followed by shade $63 \%$, shade $50 \%$, and shade $25 \%$. MSI was also significantly highest $(\mathrm{p}<0.001$ and $\mathrm{p}=0.012$ for exp. 1 and 2 respectively), in both experiments, for shade $75 \%$ followed by shade $63 \%$, shade $50 \%$, and shade $25 \%$. In contrast, EL were highest $(\mathrm{p}<0.001)$ in both experiments for shade $25 \%$ followed by shade $50 \%$, shade $63 \%$, and shade $75 \%$. 


\section{Agricultural Research \& Technology: Open Access Journal}

Table 6: Effect of shading on relative water content (RWC), membrane stability index (MSI), and electrolyte leakage (EL) of cucumber transplants during the summer season

\begin{tabular}{|c|c|c|c|}
\hline \multicolumn{1}{|c|}{ Treatment } & RWC (\%) & MSI (\%) & EL (\%) \\
\hline \multicolumn{5}{|c|}{ Summer Cucumber Exp. (1) } \\
\hline Shade 75\% & $65.56 \pm 2.62 \mathrm{a}$ & $46.54 \pm 1.57 \mathrm{a}$ & $87.90 \pm 1.22 \mathrm{~b}$ \\
\hline Shade 63\% & $58.41 \pm 4.99 \mathrm{ab}$ & $35.69 \pm 2.09 \mathrm{~b}$ & $87.81 \pm 2.34 \mathrm{~b}$ \\
\hline Shade $50 \%$ & $55.55 \pm 2.03 \mathrm{~b}$ & $28.86 \pm 1.93 \mathrm{c}$ & $93.56 \pm 1.08 \mathrm{a}$ \\
\hline Shade $25 \%$ & $52.37 \pm 1.39 \mathrm{~b}$ & $25.85 \pm 1.09 \mathrm{c}$ & $95.86 \pm 0.89 \mathrm{a}$ \\
\hline \multicolumn{2}{|c|}{ Summer Cucumber Exp. (2) } \\
\hline Shade 75\% & $71.02 \pm 3.00 \mathrm{a}$ & $50.86 \pm 2.49 \mathrm{a}$ & $91.05 \pm 1.36 \mathrm{~b}$ \\
\hline Shade 63\% & $55.10 \pm 3.13 \mathrm{~b}$ & $49.90 \pm 1.77 \mathrm{ab}$ & $92.93 \pm 1.07 \mathrm{ab}$ \\
\hline Shade $50 \%$ & $52.12 \pm 3.17 \mathrm{~b}$ & $44.89 \pm 2.65 \mathrm{bc}$ & $94.01 \pm 0.81 \mathrm{ab}$ \\
\hline Shade $25 \%$ & $40.91 \pm 1.62 \mathrm{c}$ & $42.07 \pm 1.39 \mathrm{c}$ & $94.36 \pm 0.61 \mathrm{a}$ \\
\hline
\end{tabular}

Table 7: Effect of shading on leaf $\mathrm{N}, \mathrm{P}$, and $\mathrm{K}$ concentrations of cucumber transplants during the summer season.

\begin{tabular}{|c|c|c|c|}
\hline \multicolumn{1}{|c|}{ Treatment } & N & K \\
\hline \multicolumn{7}{|c|}{ Summer Cucumber Exp. (1) } \\
\hline Shade $75 \%$ & $9.80 \pm 0.09 \mathrm{a}$ & $0.16 \pm 0.01 \mathrm{a}$ & $1.42 \pm 0.02 \mathrm{a}$ \\
\hline Shade $63 \%$ & $9.05 \pm 0.10 \mathrm{~b}$ & $0.10 \pm 0.02 \mathrm{~b}$ & $1.27 \pm 0.01 \mathrm{~b}$ \\
\hline Shade $50 \%$ & $8.70 \pm 0.14 \mathrm{~b}$ & $0.09 \pm 0.01 \mathrm{bc}$ & $1.19 \pm 0.05 \mathrm{c}$ \\
\hline Shade $25 \%$ & $8.63 \pm 0.19 \mathrm{~b}$ & $0.07 \pm 0.01 \mathrm{c}$ & $1.04 \pm 0.01 \mathrm{~d}$ \\
\hline \multicolumn{2}{|c|}{ Summer Cucumber Exp. (2) } \\
\hline Shade $75 \%$ & $9.68 \pm 0.09 \mathrm{a}$ & $0.15 \pm 0.03 \mathrm{a}$ & $1.39 \pm 0.05 \mathrm{a}$ \\
\hline Shade $63 \%$ & $9.44 \pm 0.12 \mathrm{a}$ & $0.13 \pm 0.04 \mathrm{a}$ & $1.22 \pm 0.10 \mathrm{ab}$ \\
\hline Shade $50 \%$ & $9.29 \pm 0.15 \mathrm{a}$ & $0.10 \pm 0.01 \mathrm{~b}$ & $1.15 \pm 0.02 \mathrm{~b}$ \\
\hline Shade $25 \%$ & $8.49 \pm 0.13 \mathrm{~b}$ & $0.07 \pm 0.02 \mathrm{c}$ & $0.91 \pm 0.04 \mathrm{c}$ \\
\hline
\end{tabular}

Shade level affected leaf mineral nutrient concentration but the effect differed among nutrients. Leaf $\mathrm{N}, \mathrm{P}$, and K concentrations increased with shade level (Table 7). Concentrations of leaf N, P, and $\mathrm{K}$ were significantly highest in both experiments for shade $75 \%$ followed by shade $63 \%$, shade $50 \%$, and shade $25 \%$. Leaf $\mathrm{N}$ concentration was significantly highest $(\mathrm{p}<0.001$ and $\mathrm{p}=0.007$ for exp. 1 and 2 respectively), in both experiments, for shade $75 \%$ followed by shade $63 \%$, shade $50 \%$, and shade $25 \%$. P concentration was also significantly highest $(\mathrm{p}=0.004$ and p $<0.001$ for exp. 1 and 2 respectively), in both experiments, for shade $75 \%$ followed by shade $63 \%$, shade $50 \%$, and shade $25 \%$. Similarly, K were highest $(\mathrm{p}<0.001)$ in both experiments for shade $25 \%$ followed by shade $50 \%$, shade $63 \%$, and shade $75 \%$. Values are means \pm SE $(n=6)$. Mean values in each column followed by a different lower-case-letter are significantly different by Fisher's least-significant difference test (LSD) at $\mathrm{P} \leq 0.05$. Values are means $\pm S E(n=6)$. Mean values in each column followed by a different lower-case-letter are significantly different by Fisher's least-significant difference test (LSD) at $\mathrm{P} \leq 0.05$.

\section{Discussion}

Shading nets are intended to reduce solar radiation in order to reduce heat stress especially during summer inside greenhouses.
Significant amount of work has been done on the effect of shading materials including shade clothes with varying degree of shading, shade nets, and partially shad screens $[5,12,30,31]$ to reduce the photo inhibition and/or high temperature caused by light. Our studies show that solar radiation and temperature have been strongly affected by shading level. Over the two repeats of summer cucumber experiments in which transplants were grown under different shade levels, solar radiation decreased with increased shading levels (Figure $1 \& 2$ ). Also, temperatures have been strongly affected by shading level, but the effect differed among experiments. Over the two repeats of summer cucumber, temperature decreased with increased shading levels (Figure $3 \& 4$ ).

Our results are consistent with previous reports that show that shading reduces solar radiation and air temperature [32-34]. A $30 \%$ black shading cover was found to reduce solar radiation and wind speed but did not significantly alter maximum daily air temperature as compared with open field conditions [35]. Heavy shading $(75 \%)$ on basil, strongly reduce photosynthesis rate and, effectively reduce leaf temperature when air temperature was less than $30^{\circ} \mathrm{C}[36]$. Light quality modification by colored shade nets efficiently decreases temperature compared with 
black shading. This might be due to the higher content of scattered/diffuse light [5]. The reduction in air temperature during the summer experiments under higher shade levels could be attributed to the light diffusive characteristics and the shaded environment of the black nets.

A significant reduction in air temperature due to shading was also reported in a greenhouse study on strawberry, tomato, and sweet pepper even though a different type of shading was used compared to the current study $[33,37]$. Overall this study showed that vegetative growth characteristics i.e., leaves number, leaf area, shoot length, stem diameter, shoot FW, and shoot DW, increased when shade level increased (Table 1 \& 2). Under shade condition, plants undergo morphological changes to maximize light use. Modification of the light spectrum quality and quantity via black and/or colored shade nets can act as a physiological tool to modify the crop micro-climate and enhance plant growth and productivity [5]. Plants adapted to shade have greater foliar surface and specific leaf area, thinner leaves, and taller stems compared with plants adapted to strong light 38 . Our results agree with studies showing that shaded bell peppers and tomato plants have longer internodes, larger leaves, greater whole-plant leaf area, and thinner leaves [32,34]. Results are also consistent with a cucumber and tomato study, in which shaded plants grow taller than unshaded plants, and produce a greater average internode length $[38,39]$. Plants grown in the shade tend to have a larger leaf area because cells expand more under low light intensities in order to receive light for photosynthesis [40].

At high sunlight intensities, chlorophyll degradation rate in plant leaves is higher than the synthesis rate, leading to a decrease in chlorophyll concentration as a result of chloroplast formation inhibition. Accordingly, shade leaves in comparison with sun leaves tend to show higher chlorophyll concentrations per unit of leaf weight [41]. Although the formation of carotenoids in mature fruits does not require induction by light, shaded fruits have lower content of carotenoids [42]. The carotenoid content was lowest in plants from open fields and highest in plants covered by black nets [43]. This study clearly showed that Chlorophyll a, chlorophyll b, total chlorophyll, and carotenoids increased with increased shade level (Table 3).

Although shade-grown plants are not directly exposed to sunlight, they produce additional chlorophyll a and b to capture diffuse radiation to produce the carbohydrates needed for the plant to grow, as supported by the results of [44]. Shaded lettuce leaves showed higher total chlorophyll (chlorophyll a and b) content than leaves from unshaded control plants [43]. Minimal chlorophyll fluorescence (F0) has been reported to increase with the increase of the irradiance. Reduction in the maximum photochemical efficiency of PSII (Fv/Fm) under excessive photosynthetic photon flux density (PPFD) is a widely reported phenomenon in plants [45]. Fv/Fm reduced with the increase of photosynthetic photon flux density (PPFD) levels [46]. Other studies have found Fv/Fm to be similar [47] and occasionally higher [47] in shaded plants. These results are consistent with the result of the current study (Table 4), indicating that shading increases chlorophyll a fluorescence (Fv/Fm, Fv/F0, and PI), which can serve as an indicator of the plant's photosynthetic efficiency.

When plants are exposed to the direct sunlight irradiance, they could induce some protective mechanisms such as the increases in proline, sugars, and the activity of antioxidant enzymes as reported [48]. We have observed clear decreases in free proline, soluble sugars, and total free amino acids with increased shade level (Table 5). Sugar accumulation in vegetables is mainly affected by light intensity and temperature. Consequently, exposing fruit to higher temperatures, especially during ripening, leads to an increase in the total soluble solids content (SSC), mainly due to an increase in carbohydrate biosynthetic enzyme activity and increased transpiration [49]. Pepper fruits grown in plastic shad nets had significantly lower TSS content when compared with unshaded fruits [43]. Conversely, lettuce grown under pearl (and yellow shading nets showed the highest soluble sugar content [50]. The higher blue light transmittance during the production of tomato under pearl shading nets showed higher SSC/TA ratios [51].

Our studies show that cucumber trans plants grown under higher shade levels (63 and $75 \%$ ) showed a significant increase in dehydration tolerance in terms of increased RWC and MSI and reduced EL compared to those plants grown under lower shade and/or unshaded conditions (Table 6). As a measure of plant water status, RWC reflects the metabolic activity in plant tissues, and used as a most meaningful index to identify the legumes with contrasting differences in dehydration tolerance [52]. Moderate shade alleviated the drought stress of P. cathayana not only by improving the leaf RWC but also by maintaining the positive carbon balance [53].

Over the different repeats of the experiments in which transplants were grown under different shade levels, lower shade conditions invariably caused significant reductions in leaf mineral nutrient i.e., $\mathrm{N}, \mathrm{P}$, and $\mathrm{K}$ (Table 7). This was consistent with the report [54] who showed that tissue N, P, and K levels were increased with increasing shading level [55] studied the effect of different shading levels on tomato leaves nutrient contents, especially N, P and $\mathrm{K}$. their results showed that shading had no effect on total leaf $\mathrm{N}, \mathrm{P}$ and $\mathrm{K}$ contents at the early and peak flowering stages. However, leaf N, P and K contents of 40\% shaded plants at the later flowering stage were significantly increased. There were no difference in leaf $\mathrm{N}$ and $\mathrm{K}$ contents between $40 \%$ and $75 \%$ shading treatments

\section{References}

1. Shinohara T, Leskovar, DI (2014) Effects of ABA, antitranspirants, heat and drought stress on plant growth, physiology and water status of artichoke transplants. Sci Hortic (Amsterdam) 165: 225-234. 
2. Jones PDD, Briffa KRR (1992) Global surface air temperature variations during the twentieth century : Part 1 , spatial , temporal and seasonal details. The Holocene 2(2): 165-179.

3. Taiz L, Zeiger E (2010) Plant Physiology. Annals of Botany.

4. Ilić ZS, Milenković L, Šunić L, Fallik E (2015) Effect of coloured shadenets on plant leaf parameters and tomato fruit quality. J Sci Food Agric 95(13): 2660-2667

5. Ilić ZS, Fallik E (2017) Light quality manipulation improves vegetable quality at harvest and postharvest: A review. Environ Exp Bot 139: 7990.

6. Kong Y (2013) Pearl netting affects postharvest fruit quality in Vergasa sweet pepper via light environment manipulation. Sci Hortic (Amsterdam) 150: 290-298.

7. Shahak Y (2008) Photo-Selective Netting for Improved Performance of Horticultural Crops. a Review of Ornamental and Vegetable Studies Carried Out in Israel. Acta Hortic 161-168.

8. Buthelezi MND, Soundy P, Jifon J, Sivakumar D (2016) Spectral quality of photo-selective nets improves phytochemicals and aroma volatiles in coriander leaves (Coriandrum sativum L.) after postharvest storage. J Photochem Photobiol B 161: 328-334.

9. Chang PT, Hsieh CC, Jiang YL (2016) Responses of Shih Huo Chuan pitaya (Hylocereus polyrhizus (Weber) Britt. \& Rose) to different degrees of shading nets. Sci Hortic (Amsterdam) 198: 154-162.

10. Sivakumar D, Jifon J, Soundy P (2017) Spectral quality of photoselective shade nettings improves antioxidants and overall quality in selected fresh produce after postharvest storage. Food Rev Int 0: 1-18.

11. Li S, Rajapakse NC, Young RE, Oi R (2000) Growth responses of chrysanthemum and bell pepper transplants to photoselective plastic films. Sci Hortic (Amsterdam) 84(3-4): 215-225.

12. Shahak Y, Ratner K, Giller YE, Zur N, Or E, et al. (2008) Improving solar energy utilization, productivity and fruit quality in orchards and vineyards by photoselective netting. Acta Hortic 772: 65-72.

13. Al-Helal IM, Abdel-Ghany AM (2012) Solar Radiation Transmission through Plastic Shading Nets. Acta Hortic 927: 731-738.

14. Castellano S, Candura A, Scarascia MG (2008) Relationship between solidity ratio, colour and shading effect of agricultural nets. In Acta Horticulture 801 PART 1: 253-258.

15. Wallace DH, Munger HM (1965) Studies of the Physiological Basis for Yield Differences. I. Growth Analysis of Six Dry Bean Varieties. Crop Sci 5: 343-348

16. Semida WM, El-Mageed TAA, Mohamed SE, El-Sawah NA (2017) Combined effect of deficit irrigation and foliar-applied salicylic acid on physiological responses, yield, and water-use efficiency of onion plants in saline calcareous soil. Arch Agron Soil Sci 63(9): 1227-1239.

17. Arnon DI (1949) Copper Enzymes in Isolated Chloroplasts. Polyphenoloxidase in Beta Vulgaris. Plant Physiol 24(1): 1-15.

18. Rady MM (2011) Effect of 24-epibrassinolide on growth, yield, antioxidant system and cadmium content of bean (Phaseolus vulgaris L.) plants under salinity and cadmium stress. Sci Hortic (Amsterdam) 129(2): 232-237.

19. Hayat S, Ali B, Ahmad A (2007) In Salicylic Acid: A Plant Hormone pp. 1-14.

20. Sullivan CY, Ross WM (1979) Stress Physiology in Crop Plants. In: Mussel H, Staples RC (Eds.) John Wiley \& Sons, USA, pp. 263-281.

21. Hafez AA, Mikkelsen DS (1981) Colorimetric determination of nitrogen for evaluating the nutritional status of rice. Commun. Soil Sci Plant Anal 12: 61-69.
22. Jackson ML (2005) Soil chemical analysis: Advanced course. UWMadison Libraries Parallel Press.

23. Page AI, Miller RH, Keeny DR (1982) In Part II. Chemical and Microbiological Methods. ( $2^{\text {nd }}$ edn.), American Society of Agronomy, pp. 225-246.

24. Bates LS, Waldren RP, Teare I (1973) Rapid determination of free proline for water-stress studies. Plant Soil 39(3): 205-207.

25. Irigoyen JJ, Emerich DW, Sanchezdiaz M (1992) Water-Stress Induced Changes in Concentrations of Proline and Total Soluble Sugars in Nodulated Alfalfa (Medicago sativa) Plants. Physiol Plant 84(1): 55-60.

26. Dubey RS, Rani M (1989) Influence of NaCl Salinity on Growth and Metabolic Status of Protein and Amino Acids in Rice Seedlings. J Agron Crop Sci 162(2): 97-106.

27. Maxwell K, Johnson GN (2000) Chlorophyll fluorescence-a practical guide. J Exp Bot 51(345): 659-668.

28. Spoustová P, Synková H, Valcke R, Čevrovská N (2013) Chlorophyl a fluorescence as a tool for a study of the Potato virus Y effects on photosynthesis of nontransgenic and transgenic Pssu-ipt tobacco. Photosynthetica 51(2): 191-201.

29. Clark AJ, Landolt W, Bucher JB, Strasser RJ (2000) Beech (Fagus sylvatica) response to ozone exposure assessed with a chlorophyll a fluorescence performance index. Environ Pollut 109(3): 501-507.

30. Stamps RH (2009) Use of colored shade netting in horticulture. HortScience 44(2): 239-241.

31. Semida WM, Hadley P, Sobeih W, El-Sawah NA, Barakat MAS (2013) The influence of thermic plastic films on vegetative and reproductive growth of Iceberg lettuce Dublin . Int J Agric Sci Eng 7: 593-598.

32. Kittas C, Rigakis N, Katsoulas N, Bartzanas T (2009) Influence of shading screens on microclimate, growth and productivity of tomato. Acta Hortic 807(1): 97-102.

33. Semida WM (2011) Alternative methods to enhancing the yield and quality of vegetable crops. A PhD Thesis. Fayoum University, Egypt.

34. Díaz-Pérez JC (2013) Bell pepper (Capsicum annum L.) crop as affected by Shade level: Microenvironment, plant growth, leaf gas exchange, and leaf mineral nutrient concentration. HortScience 48(2): 175-182.

35. Möller M, Assouline S (2007) Effects of a shading screen on microclimate and crop water requirements. Irrig Sci 25(2): 171-181.

36. Chang X, Alderson PG, Wright CJ (2008) Solar irradiance level alters the growth of basil (Ocimum basilicum L.) and its content of volatile oils. Environ Exp Bot 63: 216-223.

37. Aberkani K, Xiuming H, Damien de H, Martine D, Stephen V, et al (2010) Effects of shading using a retractable liquid foam technology on greenhouse and plant microclimates. Horttechnology 20: 283-291.

38. Larcher W (2003) Physiological plant ecology: ecophysiology and stress physiology of functional groups. Springer Science \& Business Media.

39. El-Abd MTG, Shanan SA, Abou-Hadid AF, Saleh MM (1994) Effect of Different Shading Densities on Growth and Yield of Tomato and Cucumber Plants. Egypt J Hortic 21: 65-80.

40. Tinyane PP, Dharini S, Soundy P (2013) Influence of photo-selective netting on plantmorphology, fruit quality and bioactive compounds in tomato cultivars. Scientia Horticulturae 161: 340-349.

41. Fu W, Li P, Wu Y (2012) Effects of different light intensities on chlorophyll fluorescence characteristics and yield in lettuce. Sci Hortic (Amsterdam) 135: 45-51 
42. Dorais M, Papadopoulos A (2001) Greenhouse tomato fruit quality. Hortic Rev 26: 239-319.

43. Ilic ZS, Milenković L, Šunić L, Barać S, Mastilović J, et al. (2017) Effect of shading by coloured nets on yield and fruit quality of sweet pepper. Žemdirbystė (Agriculture) 104(1): 53-62.

44. Beneragama CK, Goto K (2010) Chlorophyll a: b Ratio Increases Under Low-light in Shade-tolerant Euglena gracilis. Trop Agric Res 22(1): 1225.

45. Parker WC, Mohammed GH (2000) Photosynthetic acclimation of shade-grown red pine (Pinus resinosa Ait.) seedlings to a high light environment. New For 19(1): 1-11.

46. Pires MV, Almeida AAF, Figueiredo AL, Gomes FP, Souza MM (2011) Photosynthetic characteristics of ornamental passion flowers grown under different light intensities. Photosynthetica 49(4): 593-602.

47. Groninger JW, Seiler JR, Peterson JA, Kreh RE (1996) Growth and photosynthetic responses of four Virginia Piedmont tree species to shade. Tree Physiol 16(9): 773-778.

48. Prochazkova D, Sairam RK, Srivastava GC, Singh DV (2001) Oxidative stress and antioxidant activity as the basis of senescence in maize leaves. Plant Sci 161: 765-771.

49. Guillén F, Castillo S, Zapata PJ, Martínez-Romero D, Serrano M, et al. (2007) Efficacy of 1-MCP treatment in tomato fruit. 1. Duration and concentration of 1-MCP treatment to gain an effective delay of postharvest ripening. Postharvest Biol Technol 43(1): 23-27.

50. Ntsoane LM, Soundy P, Jifon J, Sivakumar D (2016) Variety-specific responses of lettuce grown under the different-coloured shade nets on phytochemical quality after postharvest storage. J Hortic Sci Biotechnol 91(5): 520-528.

51. Elad Y, Messika Y, Brand M, David DR, Sztejnberg A (2007) Effect of colored shade nets on pepper powdery mildew (Leveillula taurica). Phytoparasitica 35(3): 285-299.

52. Sinclair TR, Ludlow MM (1986) Influence of Soil Water Supply on the Plant Water Balance of Four Tropical Grain Legumes. Aust J Plant Physiol 13(3): 329-341.

53. Huang X, Xiao X, Zhang S, Korpelainen H, Li C (2009) Leaf morphological and physiological responses to drought and shade in two Populus cathayana populations. Biol Plant 53: 588-592.

54. El-Gizawy AM, Abdallah MMF, Gomaa HM, Mohamed SS (1992) Effect of different shading levels on tomato plants. 2. Yield and fruit quality. Acta Hortic 323: 349-354.

55. Liu XZ, Kang SZ, Zhang JH (2003) Dry-matter partitioning, yield and leaf nutrient contents of tomato plants as influenced by shading at different growth stages. Pedosphere 13: 263-270.

\begin{tabular}{l} 
Your next submission with Juniper Publishers \\
will reach you the below assets \\
- Quality Editorial service \\
- Swift Peer Review \\
- Reprints availability \\
- E-prints Service \\
- Manuscript Podcast for convenient understanding \\
- Global attainment for your research \\
- Manuscript accessibility in different formats \\
( Pdf, E-pub, Full Text, Audio) \\
- Unceasing customer service \\
Track the below URL for one-step submission \\
https://juniperpublishers.com/online-submission.php \\
\hline
\end{tabular}

